\title{
HIALURONO RŪGŠTIS: PERSPEKTYVOS ODONTOLOGIJOJE
}

\author{
Ričardas Kubilius, Inga Bulotienė \\ Lietuvos sveikatos moksly universiteto Odontologijos fakulteto \\ Veido ir žandikauliu chirurgijos klinika
}

Raktažodžiai: hialurono rūgštis, priedančio audinių regeneracija, minkštujjų audinių regeneracija, jungiamojo audinio regeneracija, žaizdų gijimas.

\begin{abstract}
Santrauka
Hialurono rūgštis (toliau - HA) yra labai populiarus, biologiškai suderinamas polisacharidas, pasižymintis išskirtinèmis fiziocheminèmis savybèmis, kurios skatina ją naudoti odontologijoje. HA yra natūrali minkštujjų ir jungiamujų audinių sudedamoji dalis, svarbi jų vystymuisi ir atsinaujinimui. İrodyta, kad HA gerina žaizdų gijimą ir uždegiminių ligų gydymą po dantų procedūrų. Terapijos su HA fizikinès ir cheminès savybès, biologinis prieinamumas, toleravimas ir efektyvumas daro ilgalaikị poveikị skausmo malšinimui, audinių elastingumui ir patvarumui. Papildomas gydymas HA turi ilgalaikị terapini poveikị ir yra efektyvesnis, negu gliukokortikosteroidų ir nesteroidinių vaistų nuo uždegimo (toliau - NVNU) vartojimas po chirurginių intervencijų.

Tyrimo tikslas - atlikti mokslinių publikacijų ir naujausių tyrimų, nagrinejjančių HA fizikines ir chemines savybes, sisteminę apžvalgą ir analizę. Išsiaiškinti gydomaji HA poveikį bei efektyvumą, gydant ūmias ir lètines burnos ertmès uždegimines ligas. Išanalizuoti pagrindines HA taikymo sritis odontologijoje ir įvertinti efektyviausią jos pritaikymą žaizdų ir kaulinių defektų po dantų ar žandikaulių chirurginių intervencijų, gydymui.

Metodika. PubMed, ScienceDirect, Cochrane Library, BioMed Central ir SpringerLink Information Service duomenų bazèse pagal pasirinktus raktinius žodžius buvo atrinkti anglų kalba išspausdinti moksliniai straipsniai nagrinejama tema.

Tyrimo rezultatai. Elektroninès paieškos metu iš viso rasti 184 straipsniai. Iš jų pagal atrankos kriterijus pasirinktos ir išnagrinètos 19 susijusių publikacijų, kuriose analizuotas vietinis HA skyrimas pacientams po dantų ar veido žandikaulių chirurgijos ir dantų
\end{abstract}

\begin{abstract}
implantavimo procedūrų. Išvados. Mokslinès literatūros analizè patvirtino temos aktualumą ir parodè, kad HA gali būti naudojama ir kaip pagalbinè priemonè po chirurginiu intervencijų burnos ertmeje. Klinikiniai ilgalaikiai tyrimai reikalingi patvirtinti HA preparatų terapinio naudojimo dozę, koncentraciją ir nustatyti tikslų naudojimo protokolą.
\end{abstract}

\section{Ivadas}

Nors praejo daug metų nuo HA atradimo, jos populiarumas nemažeja, o priešingai, vis dideja pirminès sveikatos priežiūros ir kitose medicinos srityse. HA plačiai naudojama dèl jos biologinio suderinamumo ir (arba) lengvo perdirbimo [1].

Pagrindiniai HA šaltiniai yra gyvūninès kilmès, tačiau gyvūnų audinių išskirta HA, kurioje yra baltymų ir DNR, gali sukelti neigiamas imunines reakcijas. Dèl šios priežasties sumažejo domejjimasis gyvūninès HA kilmės šaltiniais. HA galima gauti fermentuojant bakterijas. Šio metodo taikymas gali būti ribotas, nes yra nedidelè mutacijų ar infekcijos, susijusios su išoriniais produktais arba endobakteriniais toksinais, rizika [1].

HA yra plazminejje membranoje natūraliai pasigaminantis nesulfatinis glikozaminoglikanas. Tai viena pagrindinių ekstraląstelinès matricos sudedamujų dalių, ieinanti ị jungiamojo audinio, sąnarinio skysčio, embriono mezenchimos, stiklakūnio, odos ir daugelio kitų organų bei audinių sudèti [2]. Ši medžiaga aktyviai dalyvauja ir daugelyje žaizdos gijimo etapų, pvz., uždegimo reguliavimo, granuliacinio audinio formavimosi, epitelio formavimosi, audinio rekonstrukcijos [3].

HA molekule yra pagrindinis komponentas žaizdų gijimo etapuose tiek mineralizuotuose, tiek nemineralizuotuose audiniuose (uždegimas, granuliacinio audinio formavimasis, epitelio formavimasis ir audinių rekonstravimas) [4].

Daugybė HA funkcijų leido kurti ir naudoti HA pagrindu sukurtas biomedžiagas, kurios gydo įvairias uždegimines ligas [5]. 
Remdamiesi daugiafunkciu HA poveikiu panašių biologinių principų žaizdų ir dantenų bei kaulų gijimui, galime manyti, kad HA poveikis analogiškas mineralizuotų ir nemineralizuotų periodonto audinių gjimui [3].

Pastaraisiais metais, remiantis daugybe ịrodymų, pagrịstų duomenimis apie HA poveikị odontologijos srityje, buvo sukurtos HA formos, skirtos vartoti kartu su kitais preparatais nuo ūminių ir lètinių dantų ir dantenų ligų, pvz., papildomam audinių po burnos chirurgijos intervencijų gydymui [6].

Šiandien HA plačiai taikoma daugelyje medicinos sričių, odontologija - ne išimtis. Norint patvirtinti HA naudą, patartina atlikti tolesnius laboratorinius tyrimus ir plataus masto atsitiktinių imčių kontroliuojamus klinikinius tyrimus [4].

Tyrimo tikslas - atlikti mokslinių publikacijų ir naujausių tyrimų, nagrinejjančių HA fizikines ir chemines savybes, sisteminę apžvalgą ir analizę. Išsiaiškinti gydomaji HA poveikị bei efektyvumą, gydant ūmias ir lètines burnos ertmès uždegimines ligas. Išanalizuoti pagrindines HA taikymo sritis odontologijoje ir ịvertinti efektyviausią jos pritaikymą žaizdų ir kaulinių defektų gydymui po dantų ar žandikaulių chirurginių intervencijų.

\section{Tyrimo medžiaga ir metodika}

Pagal pasirinktus raktinius žodžius PubMed, ScienceDirect, Cochrane Library, BioMed Central ir SpringerLink Information Service duomenų bazèse buvo atrinkti anglụ kalba išspausdinti moksliniai straipsniai nagrinejjama tema.

\section{Tyrimo rezultatai ir jų aptarimas}

Hialurono rūgštis. Šio junginio pavadinimas kilęs iš graikų kalbos žodžio hyalos (stiklas), kuris nurodo jo fizikines savybes. K. Meyer ir J. Palmer pirmą kartą išgavo medžiagą iš galvijų stiklakūnio 1934 metais, o 1964 metais ji buvo sintezuota in vitro [7]. HA yra biopolimeras, sudarytas iš pasikartojančių disacharidų vienetų, apimančių D-gliukurono rūgšties ir N-acetilgliukozamino molekules, sujungtas b- (1-4) ir b-(1-3) glikozidais. Tai glikozaminoglikanų šeimos medžiagų grupé, vadinama mukopolisaharidais [8]. Šios grupès atstovams priklauso ir kiti plačiai žinomi junginiai, tokie kaip chondroitino sulfatas, heparano sulfatas ir dermatano sulfatas [1].

Priešingai nei kiti glikozaminoglikanai, HA sintetinama fibroblastų, chondroblastų ir osteoblastų ląstelių paviršiuje, tad sąveikoje su plazmos membranos receptoriais, patenka ị kaulų tarpląstelinę matricą ir skaidoma suaktyvintos hialuronidazès fermentinio komplekso [9]. HA pasižymi gerai išsaugomomis struktūrinemis savybėmis ir, susijungusi su keliais baltymais ir kolageno skaidulomis, esančiomis kaulų tarpląstelinejje matricoje, skatina ląstelių sukibimą, judrumą, migraciją ir proliferaciją [10].
Dèl vis dažnesnio HA naudojimo odontologijoje hipotezuojama, kad HA turi itakos audinių regeneracijai [11]. Mechaninès HA savybės yra prastesnès, nei kaulo, tačiau kaulų defektų modelyje HA gali būti naudojama kaip augimo faktorius ir ląstelių nešiklis. HA sumaišius su kitomis biologiškai suderintomis medžiagomis, siekiama skatinti kaulų regeneraciją. HA gali būti naudojama ir kaip dengiamoji medžiaga [11].

HA molekulè lengvai tirpsta vandenyje, pavirsta ị geli, kuris veikia kaip lubrikantas, taip pat absorbuoja vandeni, suteikia jam higroskopinių ir homeostatinių savybiu [7]. HA yra viena iš labiausiai higroskopinių molekulių, žinomu gamtoje. Kai HA įterpiama ị vandeninị tirpalą, vandenilis jungiasi tarp gretimų karboksilo ir N-acetilo grupių; ši savybė leidžia HA išlaikyti konformacini standumą ir sulaikyti vandenį. HA pasižymi ir svarbiomis viskoelastinèmis savybèmis, mažinančiomis virusų ir bakterijų įsiskverbimą ị audinį [4].

HA išskirtinè tuo, kad jos biologines funkcijas dèl fizikinių ir cheminių savybių bei specifinès sąveikos su ląstelèmis ir tarpląsteline matrica galima priskirti biologinèms molekulëms. Reikia dar daug nuveikti, norint išaiškinti biologinius HA mechanizmus audinių procesuose. Dèl unikalių fizikinių ir cheminių savybių HA produktai buvo sukurti gryno hialuronano, arba hialuronano darinių pagrindu, naudojant kryžminimą, esterinimą ar kitus cheminio modifikavimo būdus, siekiant pagerinti jų fizinę savybę. Šie hialuronano dariniai gali būti gaminami, nepažeidžiant biologinio suderinamumo, daugeliu fizinių pavidalų, pvz., milteliai, vilna, pluoštas, pusiau kietas gelis ir mikrosferos [6,7].

Pagrindinis HA veikimo mechanizmo komponentas susijęs su žaizdų gijimo procesu tiek mineralizuotuose, tiek nemineralizuotuose audiniuose (uždegimas, granuliacinio audinio formavimasis, epitelio formavimasis ir audinių rekonstravimas) [4]. Audiniuose, pažeistuose dèl traumos ar infekcijos, HA ilgosios grandinès suyra, o susidariusios mažos molekulinès masès grandinès sukelia uždegimini atsaką, ląstelių migraciją ir angiogenezę, kurios prisideda prie gijimo, nesusidarant randų [12]. Pirmajame gijimo etape padidejja HA sintezè dèl IL-8, TNF- $\alpha$ ir bakterinių polisacharidų poveikio. Tai lemia CD44 teigiamų limfocitu aktyvaciją ir uždegiminio atsako sukèlimą. Susiformavus granuliaciniam audiniui, HA vaidmuo kinta, nes ji pradeda absorbuoti laisvuosius radikalus ir sumažina oksidacinį stresą naujame audinyje [3].

Dèl daugybės teigiamų funkcijų, priskirtų HA, pastarajj dešimtmetị kuriant ir naudojant HA pagrindu sukurtas biomedžiagas, kuriomis gydomos įvairios uždegiminès ligos, buvo padaryta pažanga $[3,4]$.

HA poveikis kaulo formavimui. Kaulinis audinys yra geros struktūros ypatingas audinys, sukietejęs dèl jo sudè- 
tyje esančio kalcio [13]. Kaulinis audinys atsinaujina visą gyvenimą ir gali atsikurti. Tai vienintelis audinys, galintis išgyti be randų, tačiau jis negali savaime išsigydyti kritinio dydžio defektų, kurių rekonstrukcijai naudojamos įvairios biomedžiagos ar kaulo transplantatai [11,14-16]. Idealus kaulo transplantatas (biomedžiaga) turètų būti atsparus mechaninèms jègoms per operacijas, ekonomiškas, jo turètu būti pakankamai, nereikalaujantis antros operacijos, lengvai formuojamas ị norimą formą, lengvai pritaikomas, galètų būti laikomas ilgą laiką ir neturetų antigeno savybių [13]. Medžiagos, kurias naudojame šiandien, gali atitikti tik kai kurias iš šių savybių.

Dantų šalinimas, kaulų ligos bei traumos gali sukelti progresuojantị ir negrižtamą kaulų nykimą. Tai daro didelę ịtaką dantų estetikai, artikuliacinei fonetikai, osteointegracijai ir dantų protezų stabilumui. Tokiais atvejais tinkamai pacientų burnos reabilitacijai gali būti atliekama kaulų augmentacija ir (arba) naudojamos biomedžiagos [17].

Dèl dalyvavimo keliuose biologiniuose procesuose, susijusiuose su morfogeneze ir audinių gijimu, dèl biologinio suderinamumo, biologinio skaidumo ir neimunogeniškumo HA per pastaruosius dešimtmečius buvo plačiai ištirta kaip veiksminga audinių inžinerijos biomedžiaga [11]. Stimuliuodama ląstelių migraciją, adheziją ir nediferencijuotų mezenchiminių ląstelių proliferaciją bei skatindama jų diferenciaciją ị osteoblastines ląsteles, padeda atkurti kaulinius defektus. Dèl savo fizikinių ir cheminių savybių ji gali išlaikyti osteoindukcinius augimo faktorius vietineje aplinkoje, tarpininkauti osteoklastų adhezijai prie kaulo paviršiaus ir pagreitinti revaskuliarizaciją bei kaulų formavimąsi [17].

Brazilijoje atliktame tyrime pacientams vienu metu, laikantis standartinès technikos, buvo pašalinta po du apatinio žandikaulio premoliarus. Po intervencijos viena ertmė buvo užpildyta 1 proc. HA (maždaug $1 \mathrm{ml}$ ), kita ertmé palikta neapdorota, natūraliai užpildyta kraujo krešuliu. Ertmė buvo išmatuota (nuo apekso iki CEJ) ir padalinta ị tris trečdalius (CEJ, vidurio ir apekso). Ivvertintas galimas alveolinių matmenų kitimo pokytis tarp alveolių keteros ir palygintas su pooperaciniais duomenimis. Užpildytose HA ertmèse susidare daugiau kaulo (proc.), nei neužpildytose. Histologinès ir morfometrinès analizès parodè, kad kaulų trabekulès padidèjo 7 ir 21 dieną po danties ištraukimo, o kraujagyslių skaičius - per 7 dienas ertmėse, užlipdytose HA geliu. Akivaizdu, kad HA pagerina kaulų formavimąsi ir pagreitina gijimo procesą. Pastebètina, kad nebuvo įmanoma atlikti histologinès analizès, nes metodika neigalino atlikti kaulų biopsijos. Tyrimą ribojo ir ištraukus dantị neatlikta tūrine kompiuterinè tomografija (sutr. CBCT), galèjusi padèti geriau suprasti gijimo procesą [17].

Būsimieji klinikiniai žmonių tyrimai, apimantys rentge- nografinę kaulų formavimo diagnozę ir histologinį vertinimą, gali suteikti naują perspektyvą pagreitinti alveolių kaulų formavimąsi, naudojant HA. Vertetų ištirti HA naudojimą, siekiant ịvertinti gijimo procesą ir ne tokiose idealiose situacijose, kaip dantys, turintys periapikinių pažeidimų. Be to, HA vartojimas kartu su kitomis medžiagomis gali būti puiki strategija burnos regeneracinèje medicinoje [17].

HA poveikis žaizdų gijimo procesams. HA yra labai perspektyvus tarpininkas tarp periodonto audinių regeneracijos ir žaizdų gijimo. G. Gontiya ir S. Galgali ịrodè, kad 0,2 proc. HA gelio uždejjimas po chirurginių intervencijų, akmenų pašalinimo ir šaknų paviršiaus nulyginimo gerokai pagerino dantenų ir alveolinio kaulo parametrus ir sumažino uždegiminị infiltratą histologiškai ịvertintose vietose [18]. Šio tyrimo rezultatai parode, kad HA gali būti veiksmingas būdas, pagerinantis minkštụjų audinių gijimą ir gali būti naudojamas pooperacinio alveolinio osteito ar infekcijos profilaktikai po protinių dantų šalinimo procedūros [19].

Gydant antikoaguliantais sergančiuosius, kuriems reikia burnos chirurginių procedūrų, žaizdų gydymas kelia daug rūpesčių ir dažnai lemia nepatenkinamą gijimo procesą. O. Catanzano pateikè pažangios tvarsliavos paruošimo būdą, padedantị išvengti nekontroliuojamo kraujavimo, nes uždengia pooperacines alveolines žaizdas, ir tuo pat metu galinti greitai atpalaiduoti traneksamo rūgštị (toliau - TA). Sudètiniai alginato/hialuronano (toliau - ALG/HA) kempinių užpildai buvo paruošti tiesioginiu vidinio geliavimo metodu, po kurio prasidejo šaldymo-džiovinimo etapas. Kempinès buvo minkštos, lanksčios ir dailios išvaizdos bei nesubrendusios. Skenavimo elektronų mikroskopijos analizè patvirtino porų pobūdị. HA integracija paveikè mikrostruktūrą, sumažindama akytumą, modifikuodama vandens suvartojimo kinetiką ir padidindama atsparumą suspaudimui. TA išsiskyrimas iš ALG/HA kempinių parodè kontroliuojamą atpalaidavimą iki 3 val., o, esant HA, jis buvo greitesnis. Žmogaus kraujo krešejimo in vitro tyrimas patvirtino, kad HA užpildytos kempinès gerokai (iki 30 proc.) sumažina kraujo krešejimo indeksą. Rezultatai leidžia manyti, kad tokie tvarsčiai, įdedami ị žaizdą, galètų padèti kraujo hemostazei po dantų ištraukimo ar kitų chirurginių intervencijų burnos ertmèje, ypač pacientams, turintiems kraujo krešèjimo sutrikimų [5].

Manoma, kad HA svarbus biologinis vaidmuo, gydant odos žaizdas, nes HA odoje yra daug. Gyjant žaizdoms, hialuronano kiekis laikinai padideja granuliaciniame audinyje. Šioje apžvalgoje pateikiamos bendrosios HA fizikinès ir cheminès bei biologinès savybès ir kaip šios savybès gali būti naudojamos ịvairiuose žaizdų gijimo procesuose: uždegimo, granuliavimo ir reepitelizavimo [3].

Daugelis biologinių procesų, kuriuos sukelia hialuronanas, taip pat yra pagrindiniai žaizdų gijimo procese. Po 
sužeidimo žaizdos gijimas griežtai reguliuojamas nuosekliais etapais. Tai yra uždegimas, granuliacinio audinio formavimasis, reepitelizavimasis. Ląstelių migracija būtina granuliaciniam audiniui formuotis. Ankstyvojo granuliavimo audiniui būdinga hialurono turinti tarpląstelinè matrica laikoma palankia aplinka ląstelių migracijai. HA suteikia atvirą hidratuotą matricą, palengvinančią ląstelių migraciją, o hialuronano sintezè pati gali suteikti dinaminę jègą, palengvinančią ląstelių migraciją [3].

Ivairios HA formos naudojamos odontologijos srityje, kad pagreitetų žaizdų gijimas, sumažètų rando audiniai, apsaugotų žaizdos vietą nuo išorinių veiksnių, sumažètų tvarsčių kiekis ir pagerètų pooperacinis paciento komfortas $[11,14]$.

\section{Išvados}

1. Nors per pastaruosius kelerius metus odontologijoje gydymas pasireiškė uždegimo slopinamuoju, osteoindukciniu, bakteriostatiniu ir kitokiu teigiamu HA poveikiu, visišką jo veiksmingumą klinikinejje aplinkoje reikia tirti toliau, atliekant papildomus tyrimus.

2. Kaulų transplantacijos ir biomedžiagos yra plačiai naudojamos burnos ir žandikaulių chirurgijos srityse. Dèl ìvairių funkcijų HA yra perspektyvi biomedžiaga, rodanti kaulų gydymo pažangą, atitaisanti kaulų defektus ir pagreitinanti žaizdų gijimą.

3. HA turi daugybę savybių, kurios ją daro idealia molekule, lengvinančia žaizdų gijimą, spartinančia naudingo ankstyvo granuliacinio audinio, gijimo metu slopinančio destruktyvų uždegimą, formavimąsi ir skatinančia pakartotinę epitelizaciją bei angiogenezę.

4. Ivvertinus ir apibendrinus analizuotų straipsnių rezultatus galima teigti, kad HA gali būti naudojama kaip pagalbinè priemonė po chirurginių intervencijų, siekiant kaulo ar audinių regeneracijos. Teigiamas HA poveikis audiniams buvo patvirtintas daugumos nagrinètų straipsnių duomenimis, o neigiamos priklausomybės tarp pacientų, gydytų naudojant HA, nenustatyta.

\section{Literatūra}

1. Salwowska NM, Bebenek KA, Zadlo DA, Wcislo-Dziadecka DL. Physiochemical properties and application of hyaluronic acid: a systematic review. J Cosmet Dermatol 2016; 15(4):520-526. https://doi.org/10.1111/jocd.12237

2. Dahiya P, Kamal R. Hyaluronic acid: a boon in periodontal therapy. N Am J Med Sci 2013;5(5):309-315. https://doi.org/10.4103/1947-2714.112473

3. Chen WY, Abatangelo G. Functions of hyaluronan in wound repair. Wound Repair Regen 1999;7(2):79-89.

https://doi.org/10.1046/j.1524-475X.1999.00079.x
4. Casale M, Moffa A, Vella P, Sabatino L, Capuano F, Salvinelli $\mathrm{B}$, et al. Hyaluronic acid: perspectives in dentistry. A systematic review. Int J Immunopathol Pharmacol 2016;29(4):572-582. https://doi.org/10.1177/0394632016652906

5. Catanzano O, D'Esposito V, Formisano P, Boateng JS, Quaglia F. Composite alginate-hyaluronan sponges for the delivery of tranexamic acid in postextractive alveolar wounds. J Pharm Sci 2018;107(2):654-661. https://doi.org/10.1016/j.xphs.2017.09.026

6. Fujioka-Kobayashi M, Muller HD, Mueller A, Lussi A, Sculean A, Schmidlin PR, et al. In vitro effects of hyaluronic acid on human periodontal ligament cells. BMC Oral Health 2017;17(1):44-017-0341-1.

https://doi.org/10.1186/s12903-017-0341-1

7. Price RD, Berry MG, Navsaria HA. Hyaluronic acid: the scientific and clinical evidence. J Plast Reconstr Aesthet Surg 2007;60(10):1110-1119

https://doi.org/10.1016/j.bjps.2007.03.005

8. Ohno S, Ijuin C, Doi T, Yoneno K, Tanne K. Expression and activity of hyaluronidase in human periodontal ligament fibroblasts. J Periodontol 2002;73(11):1331-1337.

https://doi.org/10.1902/jop.2002.73.11.1331

9. Triggs-Raine B, Natowicz MR. Biology of hyaluronan: insights from genetic disorders of hyaluronan metabolism. World J Biol Chem 2015;6(3):110-120.

https://doi.org/10.4331/wjbc.v6.i3.110

10. Mueller A, Fujioka-Kobayashi M, Mueller HD, Lussi A, Sculean A, Schmidlin PR, et al. Effect of hyaluronic acid on morphological changes to dentin surfaces and subsequent effect on periodontal ligament cell survival, attachment, and spreading. Clin Oral Investig 2017;21(4):1013-1019.

https://doi.org/10.1007/s00784-016-1856-6

11. Zhao N, Wang X, Qin L, Zhai M, Yuan J, Chen J, et al. Effect of hyaluronic acid in bone formation and its applications in dentistry. J Biomed Mater Res A 2016;104(6):1560-1569. https://doi.org/10.1002/jbm.a.35681

12. Matou-Nasri S, Gaffney J, Kumar S, Slevin M. Oligosaccharides of hyaluronan induce angiogenesis through distinct CD44 and RHAMM-mediated signalling pathways involving Cdc2 and gamma-adducin. Int J Oncol 2009;35(4):761-773. https://doi.org/10.3892/ijo_00000389

13. Brydone AS, Meek D, Maclaine S. Bone grafting, orthopaedic biomaterials, and the clinical need for bone engineering. Proc Inst Mech Eng H 2010;224(12):1329-1343.

https://doi.org/10.1243/09544119JEIM770

14. Yilmaz N, Demirtas N, Kazancioglu HO, Bayer S, Acar AH, Mihmanli A. The efficacy of hyaluronic acid in postextraction sockets of impacted third molars: a pilot study. Niger J Clin Pract 2017;20(12):1626-1631.

15. Zhao N, Wang X, Qin L, Zhai M, Yuan J, Chen J, et al. Effect of hyaluronic acid in bone formation and its applications in 
dentistry. J Biomed Mater Res A 2016;104(6):1560-1569.

https://doi.org/10.1002/jbm.a.35681

16. Gocmen G, Aktop S, Tuzuner B, Goker B, Yarat A. Effects of hyaluronic acid on bleeding following third molar extraction. J Appl Oral Sci 2017;25(2):211-216.

https://doi.org/10.1590/1678-77572015-0187

17. Alcantara CEP, Castro MAA, Noronha MS, Martins-Junior PA, Mendes RM, Caliari MV, et al. Hyaluronic acid accelerates bone repair in human dental sockets: a randomized triple-blind clinical trial. Braz Oral Res 2018;32:e84-3107.

https://doi.org/10.1590/1807-3107bor-2018.vol32.0084

18. Gontiya G, Galgali SR. Effect of hyaluronan on periodontitis: a clinical and histological study. J Ind Soc Periodont 2012;16(2):184.

https://doi.org/10.4103/0972-124X.99260

19. Afat IM, Akdoğan ET, Gönül O. Effects of leukocyte- and platelet-rich fibrin alone and combined with hyaluronic acid on early soft tissue healing after surgical extraction of impacted mandibular third molars: a prospective clinical study. J CranioMaxillofacial Surg 2019;47(2):280-286.

https://doi.org/10.1016/j.jcms.2018.11.023

\section{HYALURONIC ACID: PERSPECTIVES IN DENTISTRY}

R. Kubilius, I. Bulotienè

Keywords: hyaluronic acid, hyaluronan, periodontal regeneration, soft tissue regeneration, connective tissue regeneration, wound healing.

Summary

Hyaluronic acid (HA) is a widely popular, biocompatible polysaccharide with exceptional physicochemical properties that inspire its use in dentistry. It is a natural component of soft and connective tissues and plays an important role in their development and regeneration. HA has been shown to improve wound healing, as well as the treatment of inflammatory diseases after dental procedures. The physicochemical properties, bioavailability, tolerability, and efficacy of HA therapy provide long-lasting, analgesic, tissue elasticity, and durability effects. Adjunctive therapy with HA provides a long-term therapeutic effect and is more effective than the use of glucocorticosteroids and nonsteroidal antiinflammatory drugs after surgery.

Correspondence to: inga.bulota@gmail.com

Gauta 2020-05-12 